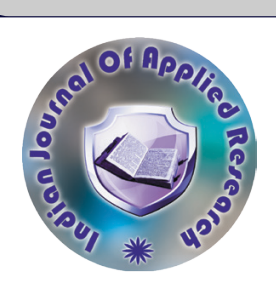

Anatomy

\title{
A MORPHOMETRIC STUDY ON HUMAN CADAVERIC PANCREAS IN ASSAMESE POPULATION
}

\begin{tabular}{l}
\hline Baro Baneswar \\
\hline Sarma Usha \\
\hline Talukdar KL \\
\hline Dutta BC \\
\hline Sarma Tapan \\
\hline Rabha Gunamani* \\
\hline
\end{tabular}

Associate Professor, Department Of Anatomy, Diphu Medical College, Diphu, Karbi Anglong, Assam, India.

Professor, Department Of Pathology, Gauhati Medical College, Guwahati, Assam, India.

Ex-HOD, Department Of Anatomy, Gauhati Medical College, Guwahati, Assam \& Principal, MGM Medical College And LSK Hospital, Kishanganj, India.

Professor and HOD, Department Of Anatomy, Diphu Medical College, Diphu, Karbi Anglong, Assam, India

Associate Professor, Fakhruddin Ali Ahmed Medical College, Barpeta, Assam, India

Assistant Professor, Department Of Anatomy, Diphu Medical College, Diphu, Karbi Anglong, Assam, India*Corresponding Author

ABSTRACT The seriousness of pancreatic diseases and the utmost importance of its correct diagnosis and treatment are expected to be helpful in correlating the functional capacity for further study in basic science and in decision making in clinical settings especially in transplant surgery of pancreas. Knowledge of normal morphometry of pancreas in living subjects is essential for understanding the segmental resection of pancreas as well as pancreatic imaging. A descriptive and cross-sectional study was conducted in the Department of Anatomy, Forensic Medicine \& Pathology of Gauhati Medical College, Guwahati from May, 2016 to December 2019 on 103 specimens of human pancreas from 13 to 78 years age of both sexes. The collected samples were divided into seven age groups: A(10-19 years), B (20-29 years), C (3039 years), D (40-49 years), E (50-59 years), F (60-69 years) and $\mathrm{G}$ ( $\geq 70$ years), for convenient description. The differences between length of pancreas were statistically significant in A vs C, A vs D, A vs E, A vs F, A vs G, B vs C, B vs D, B vs E, B vs F and B vs G. The differences between weight of pancreas were statistically significant in A vs F, B vs C, B vs G, C vs D, C vs F, D vs F, E vs F, E vs G and F vs G. The present study is expected to standardize the morphology of pancreas in Assamese population.

\section{KEYWORDS : Pancreas, Morphometry, Morphology, Specimen, Cadaver}

\section{INTRODUCTION}

Pancreas is a mixed lobulated pinkish grey coloured gland lying transversely across the posterior abdominal wall extending from the concavity of duodenum to the hilum of spleen forming the stomach bed $^{1}$. Being a mixed gland, the pancreas consists of two distinct populations of cells, the exocrine cells constituting $98 \%$ of the gland secrete enzymes into the digestive tract, and the endocrine cells $2 \%$ of the glandular mass that secrete hormones into the bloodstream ${ }^{2}$. The Endocrine pancreas is a diffuse organ scattered as small nest of cells called islets of Langerhans, which is usually numerous in tail region of the pancreas ${ }^{3}$. Islets secrete hormones that regulate blood glucose levels ${ }^{4}$. Pancreatic islets may contain a few cells or many hundreds of polygonal cells arranged in short irregular cords that are profusely invested with a network of fenestrated capillaries ${ }^{5}$

The pancreatic islet function is closely associated with the morphologic changes in islet cells ${ }^{6}$. The most common disease of the endocrine pancreas is diabetes mellitus associated with changes in the size and number of islets ${ }^{7.8}$. Moreover, male population predominantly suffers from diabetes mellitus ${ }^{4}$. Diabetes is a debilitating condition which can lead to chronic vascular, renal, and ophthalmic disease. Type I or Juvenile Diabetes is caused by the destruction of beta cells within the islets of Langerhans within the pancreas. The most promising research for diabetes mellitus is in producing stem cells where researchers are looking to make possible for diabetics to have a new pancreas ${ }^{8}$. Recently, islet cells were successfully generated in vitro from human pancreatic stem cells ${ }^{9}$. Scientists have made many advances in islet transplantation in recent years. However, most recipients returned to using insulin because the transplanted islets lost their ability to function over time. Besides, the researchers also noted that many transplant recipients were able to reduce their need for insulin, achieve better glucose stability, and reduce problems with hypoglycaemia ${ }^{10}$

Cryopreservation has been shown to enlarge transplanted cell mass, but has been accompanied by reduced viability, where a negative correlation between islet size and viability observed in non-frozen islets ${ }^{11}$. Post mortem examination of the pancreas in long-term diabetes shows an absence or greatly reduced number of insulin-staining beta cells; the residual pseudoatrophic islets contain abundant alpha cells and show light fibrosis

Literature on study of human pancreas in terms of length and weight are not available from this part of the country (North East India). The study was done considering the seriousness of pancreatic diseases and the utmost importance of its correct diagnosis and treatment. The results of the present study are expected to be helpful in correlating its functional capacity for further study in basic science and in decision making in clinical settings especially in transplant surgery.

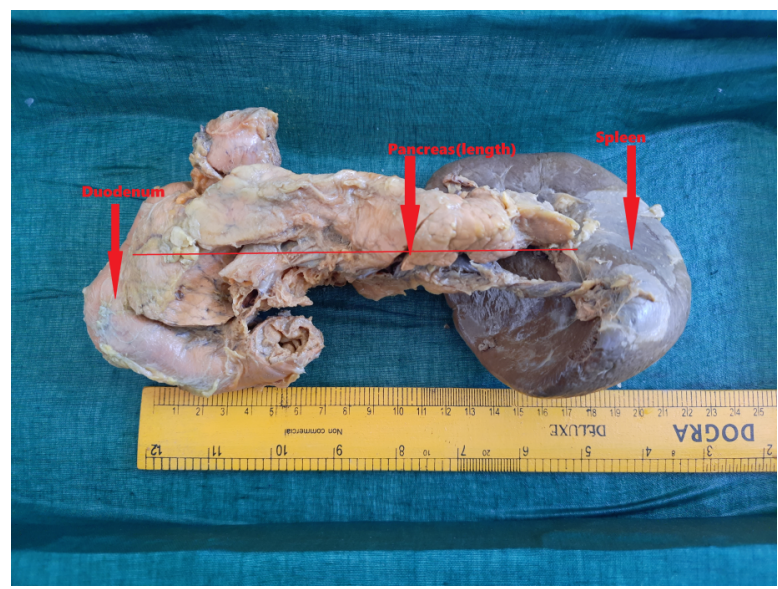

Figure 1: Pancreas, the whole length along with duodenum and spleen. The red line showing the length of pancreas.

\section{MATERIALS AND METHODS}

This descriptive and cross-sectional study was conducted in the Department of Anatomy, Forensic Medicine \& Pathology of Gauhati Medical College, Guwahati from May, 2016 to December 2019. A total of 103 specimens of human pancreas were collected from 13 to 78 years age of both sexes, excluding any visible signs of pathological changes of the viscera, any doubtful injury in pancreas, death due to known poisoning, pancreatic diseases and specimens of medicolegal 
Volume - 10 | Issue - 12 | December - 2020 | PRINT ISSN No. 2249 - 555X | DOI : 10.36106/ijar

cases. Simple random samplings were used for sampling method. This was done within 12 to 36 hours of death. During collection, approximate age, sex and cause of death were noted from record book. Then each specimen was marked with a code number for individual identification. The specimens were collected along with duodenum and spleen. After removal from the body, unwanted tissues were cleared and gently washed out in normal saline.

Measurement of length: The length of the pancreas was measured immediately after collection of the sample with the help of a meter scale. From the duodenal margin of the head to the tail in its different surfaces was considered as length and the average length was taken.

Measurement of weight: Weight was taken using digital weighing scale. It was first detached from the duodenum and the spleen and it was dried by blotting paper before measuring the weight

The collected samples were divided into seven age groups: A (10-19 years), B (20-29 years), C (30-39 years), D (40-49 years), E (50-59 years), $\mathrm{F}$ (60-69 years) and $\mathrm{G}$ ( $\geq 70$ years), for convenient description of their various age related changes (according to Varley et al.).

Statistical analysis of data: Data were collected and appropriate statistical analyses were done by using IBM SPSS version 26. Paired sample t-test was conducted to check for significant difference among the different groups for length and weight. A p-value of less than 0.05 indicates significant between two groups.

Ethical clearance: Written informed consent had been taken in English as well as in local language (Assamese) from the attendants and permission from concerned authority of post mortem cases. The study was approved by the Institutional Ethics Committee of Gauhati Medical College, Guwahati.

\section{RESULTS AND OBSERVATIONS}

The results and observations of the present study is shown in tables and bar diagrams as follows

Table - 1 Analysis Report Of Length And Weight Of Pancreas In Group A(10 To 19 Years)

\begin{tabular}{|c|c|c|c|c|}
\hline Sl. No & Age in years & Gender & Length(in cm) & Weight(in grams) \\
\hline 1. & 19 & Male & 13.56 & 87.40 \\
\hline 2. & 19 & Female & 11.20 & 78.40 \\
\hline 3. & 18 & Male & 13.56 & 87.40 \\
\hline 4. & 16 & Male & 11.20 & 78.40 \\
\hline 5. & 13 & Male & 11.20 & 78.40 \\
\hline 6. & 16 & Male & 11.40 & 79.40 \\
\hline Mean & 12.02 & \multicolumn{3}{|c|}{81.57} \\
\hline SD & 1.20 & \multicolumn{3}{|c|}{4.54} \\
\hline Minimum & 11.20 & \multicolumn{3}{|c|}{78.40} \\
\hline Maximum & 13.56 & \multicolumn{3}{|c|}{87.40} \\
\hline
\end{tabular}

Table - 2 Analysis Report Of Length And Weight Of Pancreas In Group B (20 To 29 Years)

\begin{tabular}{|c|c|c|c|c|}
\hline Sl. No & Age in years & Gender & Length(in cm) & Weight(in grams) \\
\hline 1. & 29 & Male & 14.45 & 13.64 \\
\hline 2. & 20 & Female & 11.50 & 80.12 \\
\hline 3. & 22 & Female & 12.00 & 80.00 \\
\hline 4. & 29 & Male & 14.45 & 13.64 \\
\hline 5. & 20 & Male & 11.50 & 80.12 \\
\hline 6. & 22 & Male & 12.00 & 80.00 \\
\hline 7. & 24 & Male & 11.30 & 88.40 \\
\hline 8. & 28 & Male & 11.80 & 78.80 \\
\hline 9. & 26 & Male & 10.20 & 72.50 \\
\hline 10. & 24 & Male & 14.20 & 83.50 \\
\hline 11. & 25 & Male & 10.20 & 80.50 \\
\hline 12. & 25 & Male & 10.00 & 82.50 \\
\hline Mean & 11.97 & \multicolumn{5}{|c|}{69.48} \\
\hline SD & 1.61 & \multicolumn{5}{|c|}{26.33} \\
\hline Minimum & 10.00 & \multicolumn{5}{|c|}{88.40} \\
\hline Maximum & 14.45 & \multicolumn{5}{|c|}{} \\
\hline
\end{tabular}

Table - 3 Analysis Report Of Length And Weight Of Pancreas In Group C (30 to 39 Years)

\begin{tabular}{|c|c|c|c|c|}
\hline Sl. No & Age in years & Gender & Length(in cm) & Weight(in grams) \\
\hline 1. & 37 & Male & 14.60 & 89.20 \\
\hline 2. & 32 & Male & 14.60 & 90.46 \\
\hline 3. & 39 & Female & 14.50 & 78.50 \\
\hline 4. & 36 & Female & 14.30 & 82.20 \\
\hline \hline
\end{tabular}

\begin{tabular}{|c|c|c|c|c|}
\hline 5. & 39 & Male & 14.80 & 89.20 \\
\hline 6. & 35 & Male & 14.60 & 80.60 \\
\hline 7. & 37 & Male & 14.60 & 89.20 \\
\hline 8. & 32 & Male & 14.60 & 90.46 \\
\hline 9. & 39 & Male & 14.50 & 78.50 \\
\hline 10. & 36 & Male & 14.30 & 82.20 \\
\hline 11. & 39 & Male & 14.80 & 89.20 \\
\hline 12. & 35 & Male & 14.60 & 80.60 \\
\hline 13. & 35 & Male & 13.24 & 89.50 \\
\hline 14. & 35 & Male & 14.26 & 88.50 \\
\hline Mean & 14.45 & \multicolumn{3}{|c|}{85.59} \\
\hline SD & 0.39 & \multicolumn{5}{|c|}{4.78} \\
\hline Minimum & 13.24 & \multicolumn{3}{|c|}{90.46} \\
\hline Maximum & 14.80 & \multicolumn{5}{|c|}{} \\
\hline
\end{tabular}

Table - 4 Analysis Report Of Length And Weight Of Pancreas In Group D (40 To 49 Years)

\begin{tabular}{|l|l|l|}
\hline SI. No & Age in years Gender Length(in cm) & Weight(in grams) \\
\hline
\end{tabular}

\begin{tabular}{|l|l|l|l|l|}
\hline 1. & 49 & Male & 15.00 & 80.42 \\
\hline 2. & 45 & Female 15.20 & 82.50 \\
\hline 3. & 40 & Female & 15.40 & 83.20 \\
\hline 4. & 42 & Female & 15.20 & 82.50 \\
\hline 5. & 49 & Male & 15.00 & 80.42 \\
\hline 6. & 45 & Female 15.20 & 82.50 \\
\hline 7. & 40 & Male & 15.40 & 83.20 \\
\hline 8. & 42 & Male & 15.20 & 82.50 \\
\hline 9. & 46 & Male & 14.20 & 82.50 \\
\hline 10. & 43 & Male & 15.28 & 82.56 \\
\hline 11. & 42 & Male & 15.24 & 82.60 \\
\hline 12. & 45 & Male & 12.20 & 85.50 \\
\hline 13. & 45 & Male & 13.30 & 81.50 \\
\hline 14. & 46 & Male & 12.20 & 84.50 \\
\hline 15. & 42 & Male & 13.20 & 82.00 \\
\hline Mean & 14.48 & 82.56 & \\
\hline SD & 1.17 & 1.31 & \\
\hline Minimum & 12.20 & 80.42 & \\
\hline Maximum & 15.40 & 85.50 & \\
\hline
\end{tabular}

Table - 5 Analysis Report Of Length And Weight Of Pancreas In Group E (50 To 59 Years)

\begin{tabular}{|c|c|c|c|c|}
\hline SI. No & Age in years & Gender & Length(in cm) & Weight(in grams) \\
\hline 1. & 59 & Male & 14.60 & 83.34 \\
\hline 2. & 52 & Male & 15.50 & 84.20 \\
\hline 3. & 57 & Male & 12.60 & 52.40 \\
\hline 4. & 54 & Female & 14.80 & 78.80 \\
\hline 5. & 58 & Male & 15.20 & 82.50 \\
\hline 6. & 59 & Male & 14.60 & 83.34 \\
\hline 7. & 52 & Male & 15.50 & 84.20 \\
\hline 8. & 57 & Male & 12.60 & 52.40 \\
\hline 9. & 54 & Female & 14.80 & 78.80 \\
\hline 10. & 58 & Male & 15.20 & 82.50 \\
\hline 11. & 56 & Female & 14.58 & 74.50 \\
\hline 12. & 53 & Female & 15.20 & 80.50 \\
\hline 13. & 55 & Male & 14.30 & 110.50 \\
\hline 14. & 55 & Male & 14.20 & 53.50 \\
\hline 15. & 56 & Male & 12.50 & 94.50 \\
\hline 16. & 50 & Male & 15.20 & 82.50 \\
\hline 17. & 54 & Male & 14.58 & 56.80 \\
\hline Mean & 14.47 & \multicolumn{3}{|c|}{77.37} \\
\hline SD & 0.98 & \multicolumn{3}{|c|}{15.61} \\
\hline Minimum & 12.50 & \multicolumn{3}{|c|}{110.50} \\
\hline Maximum & 15.50 & \multicolumn{3}{|c|}{} \\
\hline
\end{tabular}

Table - 6 Analysis Report Of Length And Weight Of Pancreas In Group F (60 To 69 Years)

\begin{tabular}{|c|c|c|c|c|}
\hline Sl. No & Age in years & Gender & Length(in cm) & Weight(in grams) \\
\hline 1. & 66 & Female & 12.00 & 50.56 \\
\hline 2. & 66 & Male & 13.76 & 52.50 \\
\hline 3. & 60 & Male & 14.50 & 54.50 \\
\hline 4. & 66 & Female & 12.00 & 50.56 \\
\hline 5. & 66 & Male & 13.76 & 52.50 \\
\hline 6. & 60 & Male & 14.50 & 54.50 \\
\hline 7. & 62 & Female & 15.50 & 50.50 \\
\hline 8. & 67 & Female & 13.52 & 56.50 \\
\hline
\end{tabular}


Volume - 10 | Issue - 12 | December - 2020 | PRINT ISSN No. 2249 - 555X | DOI : 10.36106/ijar

\begin{tabular}{|c|c|c|c|c|}
\hline \hline 9. & 64 & Female & 15.50 & 55.50 \\
\hline 10. & 61 & Male & 14.56 & 94.60 \\
\hline 11. & 62 & Male & 14.58 & 54.58 \\
\hline 12. & 62 & Male & 12.50 & 94.50 \\
\hline 13. & 60 & Male & 14.60 & 54.90 \\
\hline 14. & 62 & Male & 13.50 & 56.50 \\
\hline 15. & 61 & Male & 14.60 & 103.80 \\
\hline 16. & 67 & Male & 14.50 & 64.30 \\
\hline 17. & 63 & Male & 14.50 & 54.50 \\
\hline 18. & 63 & Male & 15.50 & 69.50 \\
\hline 19. & 65 & Male & 14.00 & 59.50 \\
\hline Mean & 14.10 & \multicolumn{5}{|c|}{62.33} \\
\hline SD & 1.05 & \multicolumn{5}{|c|}{16.47} \\
\hline Minimum & 12.00 & \multicolumn{5}{|c|}{103.80} \\
\hline Maximum & 15.50 & & \\
\hline
\end{tabular}

Table - 7 Analysis Report Of Length And Weight Of Pancreas In

Group G ( $\geq 70$ Years)

\begin{tabular}{|c|c|c|c|c|}
\hline SI. No & Age in years & Gender & Length(in cm) & Weight(in grams) \\
\hline 1. & 70 & Female & 12.50 & 92.20 \\
\hline 2. & 70 & Male & 14.80 & 81.80 \\
\hline 3. & 70 & Female & 12.50 & 102.20 \\
\hline 4. & 70 & Male & 14.80 & 101.80 \\
\hline 5. & 71 & Female & 13.70 & 70.80 \\
\hline 6. & 77 & Female & 14.20 & 98.80 \\
\hline 7. & 71 & Female & 13.50 & 100.80 \\
\hline 8. & 76 & Male & 15.80 & 78.70 \\
\hline 9. & 72 & Male & 14.20 & 82.60 \\
\hline 10. & 78 & Male & 14.56 & 54.20 \\
\hline 11. & 73 & Male & 16.88 & 100.60 \\
\hline 12. & 72 & Male & 13.89 & 89.80 \\
\hline 13. & 74 & Male & 13.80 & 83.88 \\
\hline 14. & 73 & Male & 14.82 & 101.70 \\
\hline 15. & 73 & Male & 13.50 & 91.80 \\
\hline 16. & 71 & Male & 14.80 & 58.90 \\
\hline 17. & 78 & Male & 15.50 & 56.56 \\
\hline 18. & 71 & Male & 14.20 & 120.80 \\
\hline 19. & 72 & Male & 14.86 & 131.84 \\
\hline 20. & 73 & Male & 14.20 & 102.60 \\
\hline Mean & 14.35 & \multicolumn{3}{|c|}{90.12} \\
\hline SD & 1.03 & \multicolumn{3}{|c|}{20.03} \\
\hline Minimum & 12.50 & \multicolumn{3}{|c|}{54.20} \\
\hline Maximum & 16.88 & \multicolumn{3}{|c|}{131.84} \\
\hline
\end{tabular}

Table - 8 Mean Length And Weight In Total Male And Female

Pancreas

\begin{tabular}{|c|c|c|}
\hline Mean & Mean length in $\mathbf{~ c m} \pm$ SD & Mean weight in $\mathbf{g m} \pm$ SD \\
\hline Total & $13.94 \pm 1.39$ & $78.27 \pm 18.29$ \\
\hline Male & $13.97 \pm 1.39$ & $78.64 \pm 19.14$ \\
\hline Female & $13.86 \pm 1.43$ & $77.00 \pm 15.28$ \\
\hline p-value & 0.751 & 0.707 \\
\hline
\end{tabular}

${ }_{\text {}} \mathrm{SD}=$ Standard Deviation

Table -9 Mean Length (in $\mathrm{Cm}$ ) Among Different Groups Of Pancreas

\begin{tabular}{|c|c|c|c|c|}
\hline Study Group & Mean & SD & Minimum & Maximum \\
\hline A & 12.02 & 1.20 & 11.20 & 13.56 \\
\hline B & 11.97 & 1.61 & 10.00 & 14.45 \\
\hline C & 14.45 & 0.39 & 13.24 & 14.80 \\
\hline D & 14.48 & 1.17 & 12.20 & 15.40 \\
\hline E & 14.47 & 0.98 & 12.50 & 15.50 \\
\hline F & 14.10 & 1.05 & 12.00 & 15.50 \\
\hline G & 14.35 & 1.03 & 12.50 & 16.88 \\
\hline
\end{tabular}

Table -10 Mean Weight (In Grams) Among Different Groups Of

Pancreas

\begin{tabular}{|c|c|c|c|c|}
\hline Study Group & Mean & SD & Minimum & Maximum \\
\hline A & 81.57 & 4.54 & 78.40 & 87.40 \\
\hline B & 69.48 & 26.33 & 13.64 & 88.40 \\
\hline C & 85.59 & 4.78 & 78.50 & 90.46 \\
\hline D & 82.56 & 1.31 & 80.42 & 85.50 \\
\hline E & 77.37 & 15.61 & 52.40 & 110.50 \\
\hline F & 62.33 & 16.47 & 50.50 & 103.80 \\
\hline G & 90.12 & 20.03 & 54.20 & 131.84 \\
\hline
\end{tabular}

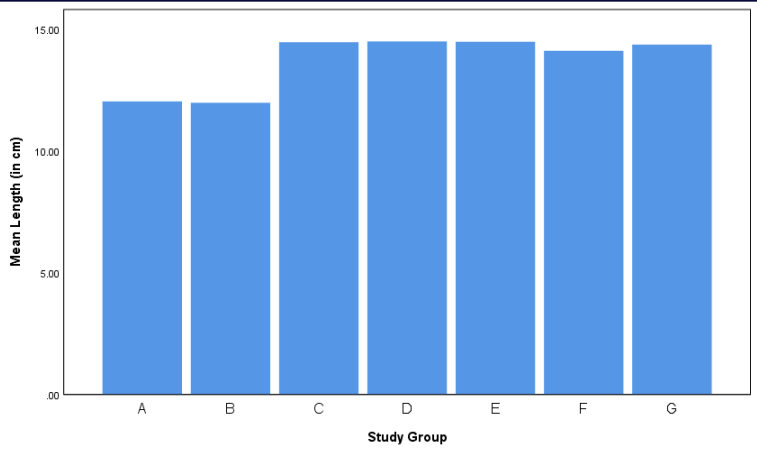

Figure2: Mean values of length(in $\mathrm{cm}$ ) among different groups

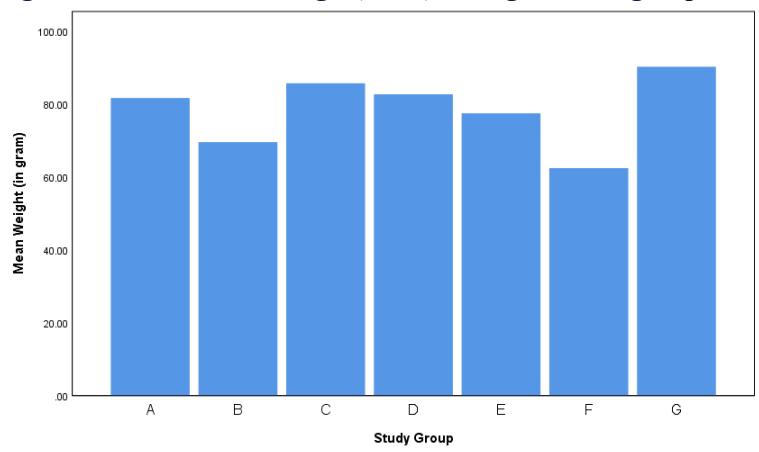

Figure3: Mean values of weight(in grams) among different groups

Table-11 Comparision Of P-values Of Length And Weight Among Different Groups

\begin{tabular}{|c|c|c|}
\hline Comparison between groups & Length p-value & Weight p-value \\
\hline A vs B & 0.944 & 0.288 \\
\hline A vs C & $<0.001$ & 0.097 \\
\hline A vs D & $<0.001$ & 0.436 \\
\hline A vs E & $<0.001$ & 0.529 \\
\hline A vs F & $<0.001$ & 0.010 \\
\hline B vs G & $<0.001$ & 0.316 \\
\hline B vs D & $<0.001$ & 0.034 \\
\hline B vs E & $<0.001$ & 0.065 \\
\hline B vs F & $<0.001$ & 0.320 \\
\hline B vs G & $<0.001$ & 0.359 \\
\hline C vs D & $<0.001$ & 0.018 \\
\hline C vs E & 0.924 & 0.025 \\
\hline C vs F G & 0.948 & 0.068 \\
\hline D vs E & 0.243 & $<0.001$ \\
\hline D vs F & 0.734 & 0.415 \\
\hline D vs G & 0.973 & 0.210 \\
\hline E vs F & 0.322 & $<0.001$ \\
\hline E vs G & 0.728 & 0.155 \\
\hline F vs G & 0.285 & 0.008 \\
\hline & 0.726 & 0.040 \\
\hline . & 0.455 & $<0.001$ \\
\hline
\end{tabular}

The differences between length of pancreas were statistically significant in A vs C, A vs D, A vs E, A vs F, A vs G, B vs C, B vs D, B vs $\mathrm{E}, \mathrm{B}$ vs $\mathrm{F}$ and $\mathrm{B}$ vs $\mathrm{G}$ (table11). In the present study, the mean values of lengths were increased with the age and it was more or less same values after group $\mathrm{C}$ (figure2). The minimum and maximum mean values were $11.97 \pm 1.61 \mathrm{~cm}$ in group B and $14.48 \pm 1.17$ in group D respectively, where the maximum value was $16.88 \mathrm{~cm}$ in group $\mathrm{G}$ and minimum value was $10.00 \mathrm{~cm}$ in group $\mathrm{B}$ (table9).

The differences between weight of pancreas were statistically significant in A vs F, B vs C, B vs G, C vs D, C vs F, D vs F, Evs F, Evs G and $\mathrm{F}$ vs $\mathrm{G}$ (table 11). In the present study, the mean value of weight was first decreased in group B and again increased in group C. Then, decreased with the age. In the last group $\mathrm{G}$ it again increased(figure3). The minimum and maximum mean values were $62.33 \pm 16.47 \mathrm{gm}$ in group F and $90.12 \pm 20.03 \mathrm{gm}$ in group $\mathrm{G}$ respectively, where the maximum value was $131.84 \mathrm{gm}$ in group $\mathrm{G}$ and minimum value was 13.64 gm in group B(table 10$)$. 


\section{DISCUSSIONS}

In the present study, the total mean length was $13.94 \pm 1.39 \mathrm{~cm}$ and the mean length of the male and female pancreas were $13.97 \pm 1.39 \mathrm{~cm}$ and $13.86 \pm 1.43 \mathrm{~cm}$ respectively. The length of pancreas was in the range of $10-16.88 \mathrm{~cm}$. Mulholland and Simeone ${ }^{14}$ have quoted a range of $12-20$ $\mathrm{cm}$. However, Kozu et $\mathrm{al}^{15}$ have quoted the range of the length of the pancreas as $10-23 \mathrm{~cm}$ long. Sulochona $\mathrm{S} .{ }^{16}$ found the length of the pancreas was in the range of 9.2 to $24 \mathrm{~cm}$ and the mean value was $16.38 \pm 2.38 \mathrm{~cm}$. The values of the present study was more or less equal to values reported by Williams et $\mathrm{al}^{17}$, Kimber et $\mathrm{al}^{18}$, Basmajian ${ }^{19}$, Minn $^{20}$, Edward $^{21}$, Garven $^{22}$, Last $^{23}$, Basmajian $^{24}$ and Bannister ${ }^{25}$. In the study of Ahmed $\mathrm{F}^{26}$ it was $18.2 \pm 0.63 \mathrm{~cm}$ and $17.2 \pm 0.25 \mathrm{~cm}$ respectively for male and female among Bangladeshi people and $\mathrm{AnackeH}^{27}$ found that the length of the pancreas varies from $16.5-27 \mathrm{~cm}$. In the study of $\mathrm{KS}$ Basnet et $\mathrm{al}^{28}$ the mean values were little bit lesser than our study in male. They found that the mean lengths in male and female subjects were $13.87 \pm 0.8 \mathrm{~cm}$ and $13.99 \pm 1.5 \mathrm{~cm}$ respectively. But, they found the total mean value for length was $14.4 \pm 1.2 \mathrm{~cm}$ which is more than our value. $\operatorname{Gore}^{29}$ has reported the length of the pancreas as $15-25 \mathrm{~cm}$ which was higher than the result of the present study.

In the present study, the mean weight of the male pancreas was $78.64 \pm$ $19.14 \mathrm{gm}$ and the female pancreas was $77.00 \pm 15.28 \mathrm{gm}$ which ranges from 13.64 to $131.84 \mathrm{gm}$. These values were lesser than the study of Ahmed $\mathrm{F}^{26}$ where they found $94.1 \pm 4.67 \mathrm{gm}$ and $91.8 \pm 2.33 \mathrm{gm}$ respectively. Ahmed H.H. et al ${ }^{30}$ found that the maximum mean weight was $122.41 \pm 0.27(\mathrm{gm})$ and minimum was $75.52 \pm 0.28(\mathrm{gm})$, the mean weight of pancreas was $87.3 \pm 30.6(\mathrm{gm})$ for ages ranged from $25-88$ years old. They mentioned that their study was a similar study with Caglar V and Kumaral $\mathrm{B}^{30}$ among Turkish people. KS Basnet et $\mathrm{al}^{28}$ studied among Nepalese people in the age with a range of 29 to 74 years which was little bit lesser value than our study. They found that the total mean weight of pancreas were $75.94 \pm 15.07 \mathrm{gm}$ and the mean weights in male and female subjects were $77.2 \pm 15.56 \mathrm{gm}$ and $72.57 \pm 15.32 \mathrm{gm}$ respectively. The present study values were lower than that of the values reported by Basmajian ${ }^{19}$. Our values were more or less equal to that values reported by $\mathrm{Kimber}^{18}$, $\mathrm{Mann}^{32}$ and Williams et $\mathrm{al}^{17}$.

Former researcher had also found the lesser weight of pancreas in females than male ${ }^{33}$.The probable reason for the smaller pancreas in female subjects may be their smaller body stature ${ }^{31}$. In the present study also the values of female were lesser than male.

Due to decline in the glandular tissue as well as the fatty connective tissue within the substance of the gland in elderly people and thinning atrophy of the gland is noticeable on CT scanning. ${ }^{34}$ In the former study also it was mentioned and found the similar result. ${ }^{31,33}$ Researchers had found that lifestyle, occupational and reproductive factors were also associated with causation of diabetes and pancreatic cancer. ${ }^{35}$ The clinical entities like these have direct association with the reduced pancreatic size. ${ }^{36,37}$ In the former study they mentioned that the reduced length and weight of pancreas in elderly people was suggestive of degenerative change of pancreas with age and some cases might also be subjected to chronic disease. ${ }^{28}$ But in our study the values were increased in the extreme age.

Due to the chemical action of formaldehyde the result obtained from similar study done on unembalmed body could change in the values of pancreas. But, Schaefer $\mathrm{JH}^{33}$ observed and commented that there was no change in weight of pancreas after embalming.

\section{CONCLUSIONS}

Knowledge of normal morphometry of pancreas in living subjects is essential for understanding the segmental resection of pancreas as well as pancreatic imaging. Pancreatic imaging has improved with the introduction of USG, CT, endoscopic retrograde cholangiopancreato graphy and selective angiography in recent days. Racial variation and geographical distribution may attribute dissimilarities among different age group. The present study is expected to standardize the morphology of pancreas in Assamese population.

\section{ACKNOWLEDGEMENT}

We acknowledge the entire faculties and staffs in the Department of Anatomy, Gauhati Medical College, Guwahati Assam.
2. Anatomy. 40th Ed. Churchill Livingstone, Elsevier, 1183-90. Functional and Clinical Anatomy Mosby, 277-9.

3. Glass J, Mundy AR.(2005). Abdomen and pelvis. In: Standring S, Ellis H, Healy JC, et al. eds. Gray's anatomy: the anatomical basis of clinical practice. 39th ed. Edinburgh: Elsevier Churchill Livingstone.

4. Kumar V, Abbas AK, Fausto N,(2004). eds. Robbins and Cotran pathologic basis of disease. 7 th ed. New Delhi: Saunders.

5. Mescher AL.(2010). Junqueira's basic histology: text and atlas. 12th ed. Baltimore: McGraw-Hill.

6. Kreel L, Sandin B.(1973). Changes in pancreatic morphology associated with ageing. Gut;14:962-70. http://dx.doi.org/10.1136/gut.14.12.962

7. Burghen GA, Murrell LR(1989). Factors influencing isolation of islets of Langerhans. Diabetes;38:129-32.

http://dx.doi.org/10.2337/diab.38.1.S129

8. Robertson RP.(2004). Islet transplantation as a treatment for diabetics- a work in progress. New Engl J Med;350:694-705. http://dx.doi.org/10.1056/NEJMra032425

9. Yeo ZX, Zhou DS(2004). In vitro cultivation of human fetal pancreatic ductal stem cells Yeo ZX, Zhou DS(2004). In vitro cultivation of human fetal pancreatic ductal stem cells
and their differentiation into insulin-producing cells. World J Gastroenterol;10:1452-6.

10. Gepts W.(1981). Islet changes in human diabetes. In: Cooperstein SJ, Watkins D, eds. The islets of Langerhans. New York: Academic Press.

11. von Mach MA, Schlosser J, Weiland M, et al.(2003). Size of pancreatic islets of Langerhans: a key parameter for viability after cryopreservation. Acta Diabetol;40:1239. http://dx.doi.org/10.1007/s00592-003-0100-4

12. Peter In't Velt. http://dx.doi.org/10.14496/dia.21040851305.28

13. Varley PF, Rohrmann CA Jr., Silvis SE, et al.(1976). The normal endoscopic pancreatogram. Radiology;118:295-300.

14. Mulholland MW, Simeone DM. Pancreas(1999). Anatomy and Structural Anomalies. In: Textbook of Gastroenterology. 3rd Ed. Vol. 1; Williams \& Wilkins, Philadelphia; In: Textbook

15. Kozu T, Suda K, Toki F.(2002). Development of pancreas and biliary duct. In: Gastrointestinal disease: An Endoscopic Approach. 2nd Ed. Slack Incorporated. USA.; $978-979$.

16. S Sulochana \&T Sivakami(2012). A gross morphological study of the pancreas in human cadavers, National Journal of Clinical Anatomy, Vol.-1, (2) Pg. 55-60.

17. Williams PL, Warwick R, Dyson M, Bannister HL,(1989). editors. The pancreas. Gray's Anatomy. 37th ed. Edinburgh:Churchill Livingstone; p. 1140-53.

18. Kimber DC, Gray CE, Stackpole CE.(1961). Human pancreas. Anatomy and physiology. 14th ed. New York: The Macmillian Company;p.495.

19. Basmajian JV.(1972). Grant's method of Anatomy. 8th ed. Baltimore: The Williams and Wilkins Company;. p.429.

20. Minn RMHM(1990).editor. The pancreas. Last's Anatomy. 10th ed. New York: Churchill Livingstone;. p.351.

21. Edward LF(1959). The pancreas. Concise anatomy. 2nd ed. New York: McGraw-Hill. p. 420 .

22. Garven HSD(1962).. Pancreas. A student's histology. 2nd ed. Edinburgh:E\&S Living stone Ltd;.p. 444

23. Last RJ(1988).. The Pancreas. In: Anatomy, Regional and Applied. 6th Edition. Churchill Livingstone. Edinburgh : 303 .

24. Basmajian JV.(1980). Grants method of Anatomy; 10th Ed. Baltimore: Williams and Wilkins: $170-173$

25. Bannister HL.(2000). Pancreas, Liver and Gall Bladder. In: Gray's Anatomy; 38th edition. Churchill Livingstone. Philadelphia : 1790-91

26. Ahmed Firoz (2010).A Gross Morphological Study of Human Postmortem Pancreas in Bangladeshi People Bangladesh J. Anat. 2010; 8(2):56-58

27. Anacker H.(1975). Radiological Anatomy of the Pancreas. In: Anacker. H, ed Efficiency and limits of Radiological Examination of the pancreas. Stuttgart: Georg Thieme; 23-24.

28. KS Basnet, TP Thapa, RP Upreti, PMS Dangol, RN Shrestha and S Dhungel(2011).A morphometric study of human pancreas in Nepalese people, Nepal Med Coll J; 13(2): 88-91.

29. Gore RM.(1994). Normal Anatomy and Examination Techniques. In: Textbook of Gastrointestinal Radiology. 1st Ed. Vol. 2; W.B.Saunders, Philadelphia; 2096-2105.

30. Ahmed H. Hussein, Abdul - Jabbar Jameel, Samira abdul Hussain(2016). Histological, Morphological and Sonographical Study of age related changes in Human Pancreas, Kirkuk University Journal /Scientific Studies (KUJSS) Volume 11, Issue 1, March 2016,p.p(104-113) ISSN 1992 - 0849, Web Site: www.kujss.com

31. V.Caglar, B. Kumral Ramazan Uygur, Ozan Alper Alkoc, Oguz Aslan Ozen and et al.(2014). Study of Volume, Weight and Size of Normal Pancreas, Spleen and Kidney in Adults Autopsies. Forensic Medicine and Anatomy Research,; 2: 63-69.

32. Mann CV, Russell RCG,(1991) editors. Pancreas. Bailey \& Loves short practice of Surgery. 21st ed. London: Chapman \& Hall;. p.077.

33. Schaefer JH.(1926). The Normal Weight of Pancreas in the adult human being: A biometric study. The Anat Rec; 32: 119-32.

34. Standring S.(2005). Pancreas. Grays Anatomy. The Anatomical Basis of Clinical Practice 39th Ed. Churchill Livingstone. Edinburg London New York; 1231-7

35. Lo AC, Soliman AS, El-Ghawalby N et al.(2007).Lifestyle, Occupational, and Reproductive Factor in Relation to Pancreatic Cancer Risk. Pancreas. ; 35: 120-9

36. Vesterhus M, Haldorsen IS, Ræder H, Molven A, Njølstad PR.(2008). Reduced Pancreatic Volume in Hepatocyte Nuclear Factor 1A-Maturity-Onset Diabetes of the Young. J Clin Endocrinol Metabol; 93: 3505-9.

37. Bock T, Pakkenberg B, Buschard K.(2005). Genetic Background Determines the Size and Structure of the Endocrine Pancreas. Diabetes; 54: 133-7. 